sta.t (B)

SEP $161997^{\circ}$ ENGINEERING DATA TRANSMITTAL

1. EDT 620242

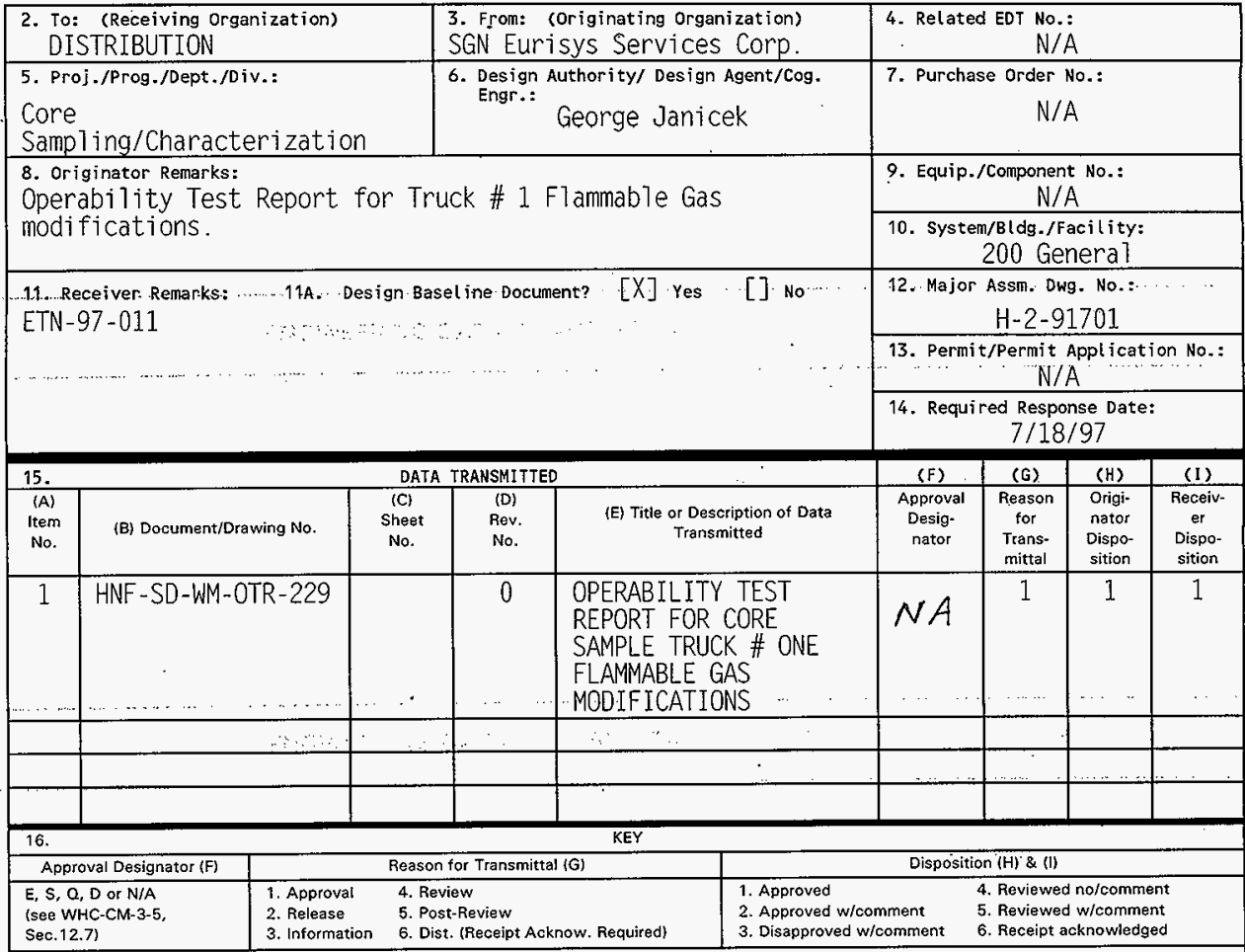

17. SIGNATURE/DISTRIBUTION

(See Approval Designator for required signatures)

\begin{tabular}{|c|c|c|c|c|c|c|c|}
\hline $\begin{array}{c}\text { (G) } \\
\text { Rea- } \\
\text { son }\end{array}$ & $\begin{array}{c}\text { (H) } \\
\text { Disp. }\end{array}$ & (J) Name & $\begin{array}{lll}\text { (K) Signature } & \text { (L) Date } & \text { (M) MSIN }\end{array}$ & $\begin{array}{l}\text { (G) } \\
\text { Rea- } \\
\text { son }\end{array}$ & $\begin{array}{c}(H) \\
\text { Disp. }\end{array}$ & \multicolumn{2}{|c|}{$\begin{array}{llll}\text { (d) Name } & \text { (K) Signature } & \text { (L) Date } & \text { (M) MSIN }\end{array}$} \\
\hline 3 & $\overline{6}$ & \multicolumn{2}{|c|}{ Design Authority George Janicek See Block s7-12 } & 1,2 & 1 & \multicolumn{2}{|c|}{ CPO Ted Jareckizz $\longrightarrow$ /28/47 s7-03 } \\
\hline $.1,2$ & 1. & \multicolumn{2}{|c|}{ Design Agent Galen wilson $/ 7 / / / h_{1} 8 / 8 / 97,57-12$} & 1,2 & 1 & \multicolumn{2}{|c|}{ 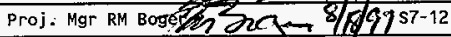 } \\
\hline 1,2 & 1 & \multicolumn{2}{|c|}{ 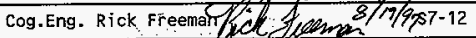 } & & & \multicolumn{2}{|c|}{$C$} \\
\hline 1,2 & 1 & \multicolumn{6}{|c|}{ cog. Mgr. John Schofield /h } \\
\hline & & \\
\hline & & \multicolumn{6}{|l|}{ Safety } \\
\hline & & \multicolumn{6}{|l|}{ Env. } \\
\hline \multicolumn{3}{|c|}{$\begin{array}{l}18 . \\
\text { JC Akers } \\
\frac{1}{C \text { Agnature of EDT }} 8 / 8 / 97 \\
\text { Originator }\end{array}$} & $\begin{array}{l}19 . \\
\text { Authorized Represehtative } \\
\text { for Receiving-Organtization }\end{array}$ & $\begin{array}{l}20 . \\
\text { GP Janicek } \\
\text { Design Auti } \\
\text { Cognizant N }\end{array}$ & Dhen: & $\frac{1 / 5 / 97}{\text { Date }}$ & $\begin{array}{l}\text { 21. DOE APPROVAL (if required) } \\
\text { Ctrl. No. W/A } \\
\text { [] Approved . } \\
\text { [] Approved w/comments } \\
\text { [] Disapproved w/comments }\end{array}$ \\
\hline
\end{tabular}

BD-7400-172-2 (05/96) GEF097 


\title{
OPERABILITY TEST REPORT FOR CORE SAMPLE TRUCK \# ONE FLAMMABLE GAS MODIFICATIONS
}

\author{
JC Akers
}

SGN Eurisys Services Corp. . Rich7and. WA 99352

U.S. Department of Energy Contract DE-AC06-96RL13200

$\begin{array}{ll}\text { EDT/ECN: } 620242 & \text { UC: } 721 \\ \text { Org Code: } 08 E 00 & \text { Charge Code: } E 51771 \\ \text { B\&R Code: EW3120074 } & \text { Tota1 Pages: } 2425 \mathrm{kmB} / \mathrm{s} / \mathrm{m}\end{array}$

Key words: CORE, SAMPLE, TRUCK, STANDING ORDER, BIO, CST, Remote Latch Unit, RLU, FLAMMABLE GAS, Purge, Qui 17 Rod, ETN-97-0011

Abstract: This report primarily consists of the original test procedure used for the Operability Testing of the flammable gas modifications to Core Sample Truck \# One. Included are exceptions, resolutions. comments, and test results.

TRADEMARK DISCLAIMER. Reference herein to any specific comercial product, process, or service by trade name, tradenark, manufacturer, or otherwise, does not necessarily constitute or imply its endorsement, recommendation, or favoring by, the United States Government or any agency thereof or its contractors or subcontractors.

Printed in the United States of America. To obtain copies of this document, contact: Document Contral Services, P.O. Box 950, Mailstop H6-08, Richland WA 99352, Phone (509) 372-2420;

Fax (509) 376-4989.
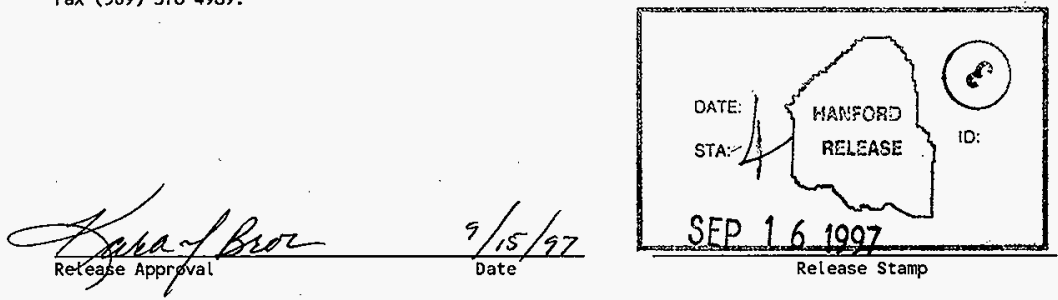

Approved for Public Release 


\section{BACKGROUND}

This report documents the testing of a modification to the Push Mode Core Sample Truck \# 1 for operation in flammable gas tanks. The modification added a system to pressurize under the Shielded Receiver (SR) weather cover to prevent flammable gas from accumulating under the SR weather cover. The system also provides indication of the pressure level and an alarm for pressurization system failure.

\section{SUMMARY}

This report consists of the original, completed, test procedure used for the operability Testing of the flammable gas modifications to the Push Mode core Sample Truck \# 1.

Prior to the Acceptance/Operability test the truck \# 1 operations procedure (T0-080-503) was revised to be more consistent with the other core sample truck procedures and to include operational steps/instructions for the SR weather cover pressurization system. A draft copy of the operations procedure was used to perform the Operability Test Procedure (OTP). A Document Acceptance Review Form is included with this report (last page) indicating the draft status of the operations procedure during the OTP.

During the OTP 11 test exceptions were encountered. Of these exceptions four were determined to affect Acceptance Criteria as 1isted in the OTP. Section 4.7 ACCEPTANCE CRITERIA. The Acceptance Criteria are based on the design requirements specified in WHC-SD-WM-FDC-048, FUNCTIONAL DESIGN CRITERIA FOR CORE SAMPLING IN FLAMMABLE GAS WATCH LIST TANKS. The exceptions are summarized in the following table. A detailed list of exceptions and resolutions is in the OTP, Section 10.0. EXCEPTIONS/RESOLUTION DATA SHEET.

\begin{tabular}{|c|c|c|c|}
\hline $\begin{array}{l}\text { EXCEPTION } \\
\text { NUMBER }\end{array}$ & $\begin{array}{l}\text { ACCEPTANCE } \\
\text { CRITERIA }\end{array}$ & $\begin{array}{l}\text { DESCRIPTION OF } \\
\text { EXCEPTION }\end{array}$ & DESCRIPTION OF RESOLUTION \\
\hline $1 \& 7$ & NO & NITROGEN TRAILER INOPERABLE & $\begin{array}{l}\text { NITROGEN TRAILER NOT REQUIRED, USED } \\
\text { BREATHING AIR COMPRESSOR TO PERFORM } \\
\text { TEST }\end{array}$ \\
\hline 2 & NO & $\begin{array}{l}\text { ELECTRICAL POWER DISTRIBUTION } \\
\text { TRAILER (EPOT) NOT USED }\end{array}$ & $\begin{array}{l}\text { EPDT NOT NEEDED, CONNECTED TRUCK } \\
\text { DIRECTLY TO ELECTRICAL GENERATOR }\end{array}$ \\
\hline 3 & YES & $\begin{array}{l}\text { ELECTRICAL CORD INTERFERENCE \& } \\
\text { PURGE SUPPLY HOSE TO LONG }\end{array}$ & $\begin{array}{l}\text { REROUTED ELECTRICAL CORD \& SECURED } \\
\text { HOSE }\end{array}$ \\
\hline $4 \& 5$ & YES & $\begin{array}{l}\text { PURGE SUPPLY HOSE TO SHORT } \\
\text { DURING FULL TRAVERSE \& BUNGEE } \\
\text { CORD HOOK PINCHES HOSE }\end{array}$ & $\begin{array}{l}\text { REPLACED WITH LONGER AND LESS } \\
\text { RESIRICTIVE BUNGEE CORD }\end{array}$ \\
\hline 6 & YES & $\begin{array}{l}\text { SLEW TRAVEL IN BOTH DIRECTIONS } \\
\text { STRETCHES \& COLLAPSES HYDRAULIC } \\
\text { HOSES \& CONTACTS SAFETY RAIL \& } \\
\text { CONDUIT }\end{array}$ & $\begin{array}{l}\text { ADDED A CAUTION BLOCK TO OPS } \\
\text { PROCEDURE TO-080-503 REV. F TO NOT } \\
\text { SLEW MORE THAN 2" IN ANY DIRECTION }\end{array}$ \\
\hline $8,9 \& 10$ & No & $\begin{array}{l}\text { GREEN PURGE LIGHT DIDN'T } \\
\text { ILLUMINATE \& ALARN LIGHT } \\
\text { RESPONDED AT } .8^{\prime \prime} H_{2} \mathrm{O} \text { INSTEAD OF } \\
.3^{\prime \prime} \mathrm{H}_{2} \mathrm{O}\end{array}$ & $\begin{array}{l}\text { REPAIRED AIR LEAKS PER ECN } 631341 \text {, } \\
\text { LEAKS IDENTIFIED BETWEEN THE SAMPLE } \\
\text { HOIST BOX AND THE BASE PLATE }\end{array}$ \\
\hline $8 a$ & NO & $\begin{array}{l}\text { UNABLE TO VERIFY PRESSURE WITH } \\
\text { INSTALLED GAUGE }\end{array}$ & $\begin{array}{l}\text { USED CALIBRATED METER TO VERIFY } \\
\text { PRESSURE \& PRESSURE SWITCH TRIP } \\
\text { SETTINGS }\left(.4^{11-}-6^{\prime \prime} \mathrm{H}_{2} 0\right)\end{array}$ \\
\hline
\end{tabular}


HNF-SD-WM-OTR-229, REV. 0

PAGE 2 OF 24

\section{CONCLUSION}

A11 acceptance criteria, as listed in Section 4.7 ACCEPTANCE CRITERIA, has been met and al1 exceptions have been documented and satisfactori $7 y$ resolved. The OTP was successfully completed and documented in Section 9.0. TEST COMPLETION. SIGN-OFF. 


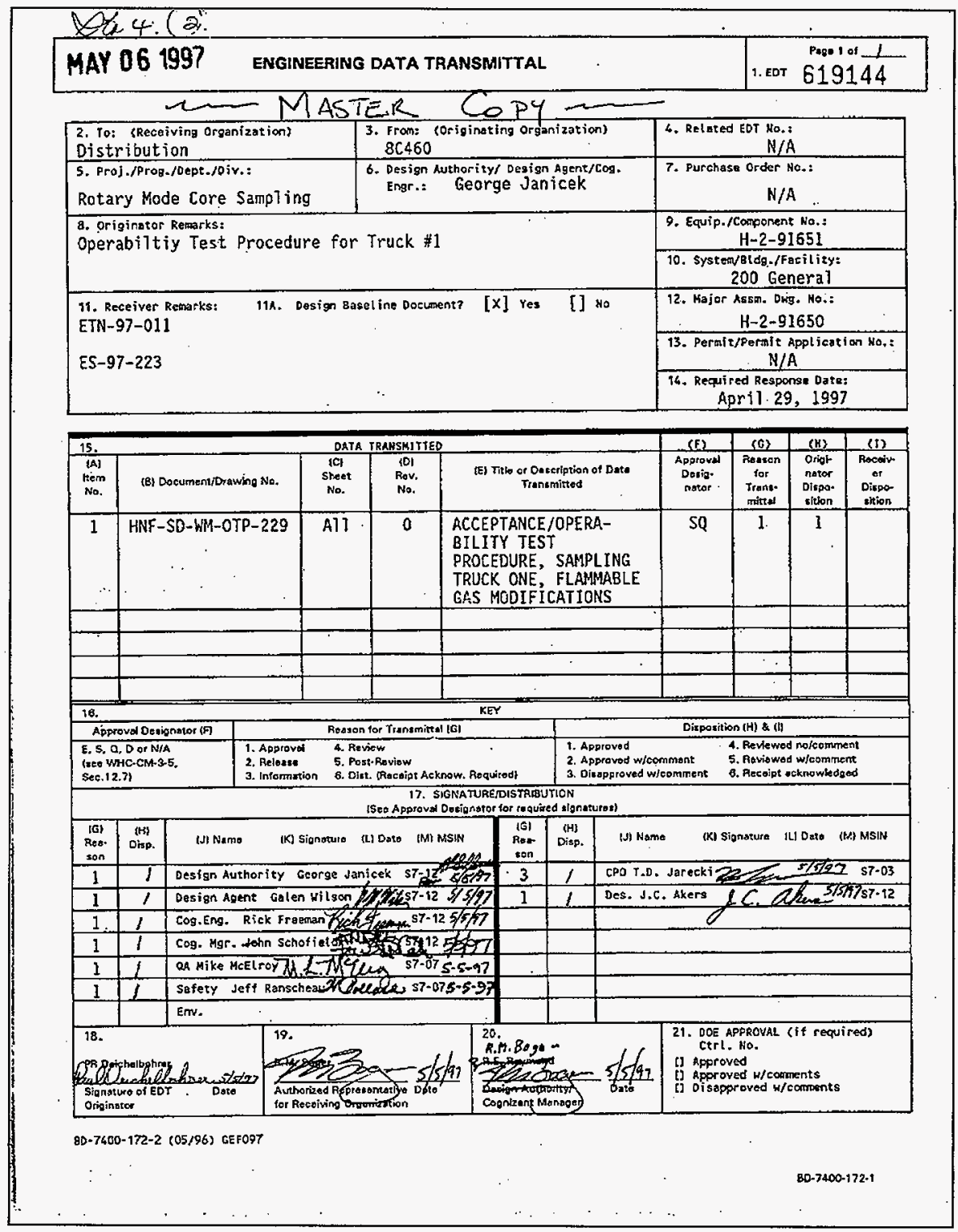




\section{ACCEPTANCE/OPERABILITY TEST PROCEDURE, SAMPLE TRUCK ONE, FLAMMABLE GAS MODIFICATIONS}

\section{Paut Deicheibohrer}

Numatec Hanford Co., Richland, WA 99352

U.S. Department of Energy Contract OE-ACO6-96RL13200

EDT/ECN: 619144

Org Code: $8 \mathrm{C} 450$

UC: 721

B\&R Code: EH3120074

Charge Code: N4H2B

Total Pages: $17 / 9$, ims $5 \% / \%$ T

Key Words: Push Mode Sampling, Z-purge, nitrogen, burst disk

Abstract: Core Sampling Truck Number One was upgraded for use with flamable gas tanks. Principally, the upgrade consists of installation of a gas purge of the truck's weather cover.

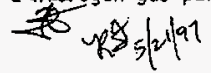

TRADEMARK DISCLAIWER, Reference herein to ony spectfle camercial product, process, or servite by trade name, tradenark, manuf acturer, or otheruise, does not necessarily constitute or imply its endorscment, reecrmendation, or fayoring by the United States Goverment or any agency thereof or

its contrectors or subcontraczors.

Printed in the United states of Americe. To obtain capies of this docment, contact: Document contral Services, P.0. Box 950, Maitstop k6.08, Richland WA 99352, Phone (509) 372-2420;

Fax (509) $376-6989$.
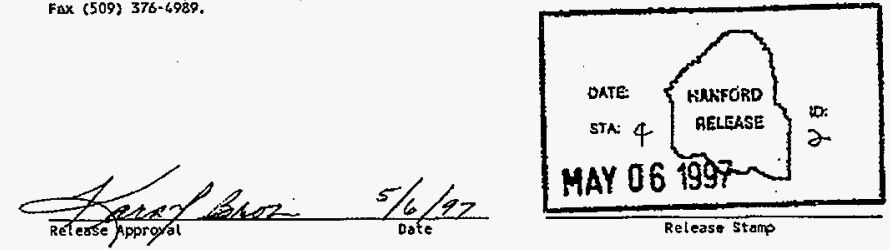

Approved for Public Release

A-6400.073 (01/97) GEF321 
TABLE OF CONTENTS

1.0 PURPOSE

2.0 SCOPE

3.0 RESPONSIBILITIES

4.0 INFORMATION

4. 1 TEST GUIDANICE

3

4.2 REFERENCES

4.3 SAFETY ISSUES

4.4 RADIATION ANO CONTAMINATION CONTROL

4.5 OUALITY ASSURANCE

4.6 TYPE Z PRESSURIZATION SYSTEM

4.7 ACCEPTANCE CRITERIA. . . . . . . . . . . 5

5.0 RECOROS

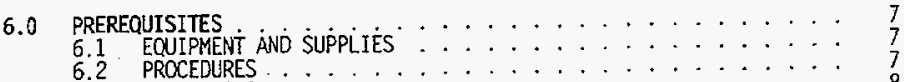

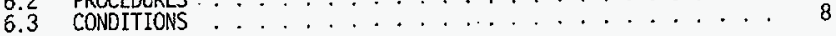

7.0 TEST PROCEDURE (EQUIPNENT)

7.1 EQUIPMENT IDENTIFICATION AND SETUP ...........

7.2 CORE SAMPLE TRUCK START UP . . . . . . . . . . . 9

7.3 ORILL RIG MANEUVERING . . . . . . . . . . . . . . . . . 9

7.4 TYPE Z PRESSLIRIZATION SYSTEM TEST WITH NITROGEN $\ldots \ldots \ldots$

7.4 TYPE 2 PRESSURIZATION SYSTEM TEST WITH AIR ....... 12

7.6 SHUT DOWN . . . . . . . . . . . 14

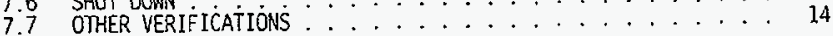

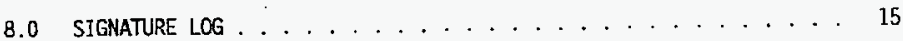

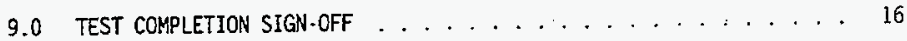

10.0 EXCEPTIONS/RESOLUTION DATA SHEET . . . . . . . . . . . . . . 17 


\subsection{PURPOSE}

The purpose of this system acceptance/operability test procedure is to provide instructions for system acceptance and operability testing of the push mode core sampler system modified for use on flammable gas tanks. This testing fulfills the applicable requirenents of WHC-SD-WM-FDC-048. Section 5.9 and WHC-CM-6-1, EP-4.2.

Testing will be imited to testing the modifications completed on Core Sampler Truck 1 to instal] the Type $Z$ pressurization system for shielded receiver weather cover and the modification of shielded receiver lifting frame to install stronger hydraulic cylinders.

\subsection{SCOPE}

System operability testing of the Push Mode Sampling System will verify that system design requirements. as well as functional and operational requirements, have been met. Testing will invoive operating the Push Mode equipment to demonstrate acceptable operation of the Type $Z$ pressurization systern and shielded receiver lifting frame modification to perform tasks required during sampling of flammable gas tanks. Testing will a 750 verify the compatibility of required ancillary equipment such as generator, breathing air compressor. and nitrogen trailer.

The test(s) will be performed in the "Dean Dome" located. east of the 2704H building.

\subsection{RESPONSIBILITIES}

Safety. QA. Characterization Project Operations (CPO). Characterization Engineering (CE). and Characterization Field Engineering (CFE) shail approve this test procedure (hereafter referred to as the OTP). prior to its release. Responsibilities are as follows:

Operations Test Director

Responsible for the overall performance of the OTP. Responsible for the proper conduct of operations for the entire test site as well as all personnel involved in the testing. Ensures the execution of all testing activities are within the scope of the OTP. Exercises stop work authority for unsafe conditions within the scope of the OTP. Directs actions to be taken to prevent injury to employees or damage to equipment. Acts through the push mode sampling PIC for the proper performance of ait operations at the test site. Receives technical advice from CE and CFE engineers on system and equipment design parameters. Maintains cognizance of test. exceptions as documented by the CFE Cognizant engineer and the resolution of same. Concurs with all changes and with the acceptability of the equipment modifications by signing the OTP. 
Care Sampling PIC (Person In Charge)

Responsible for the assignment of personnel and directing the operation of the various systems. Controls configuration and access to the test area in order to maintain a safe environment. Aids the Cognizant Engineer in maintaining configuration control. Approves changes to the OTP in terms of operational steps or equipment configuration with concurrence of CE and CFE Cognizant engineer and Operation Test Director. Conducts a pre-job safety meeting at the start of each shift during the performance of the OTP. Briefs the personnel on testing to be performed that day and associated hazards.

CFE Cognizant Engineer

Provides on-site technical expertise and advice to the PIC and Test director as required. Controls the sequence in which the OTP is conducted through the Test Director and with concurrence of CE. Maintains configuration control on the "Exception/Resolution Data Sheet." Resolves exceptions with the concurrence of $\mathrm{CE}$ and the assigned Quality Engineer for those exceptions relating to the items which initially required Quality verification. Concurs with the acceptability by signing the OTP.

Characterization Engineering (CE)

Provides on-site technical expertise and advice to the PIC and Test Director as required. Advises Cognizant Engineer and Test director on equipment capabilities, recommends test sequence changes, and test requirements. Responsible for issuing any Engineering Change Notices (ECH's) required to support maintaining configuration control during testing. Approves any changes to the OTP. Responsible for obtaining additional support from engineering. Reviews and approves test procedure and test report. Obtains Design Authority approval of test procedures and test report. Resolves any designer/project related deficiencies. These personne i may be from the CE organization or designated by $\mathrm{CE}$ management.

Core Sampling Operations Management. Responsible through the Operations Test Director for the overall testing program. Review and approves test procedures. Ensures Pre-Job safety meeting is held prior to test start. Monitors testing to extent approval may be given for satisfactory equipment operability.

Core Sampline operators Conducts testing according the OTP procedures directed by the Operations PIC. Notifies the PIC of concerns. exceptions and off-normal canditions during testing.

Quality Assurance Reviews and approves test procedure to assure compliance with appropriate regulations. Resolves exceptions requiring quality verification jointly with CFE Cognizant Engineer. Quality verification of exceptions is anly necessary for those exceptions relating to items which initially required Quality verification. 
HNF-SD-WM-OTP-229. REV 0 PAGE 3 OF 17

Safety

Reviews and approves test procedure to assure compliance with applicable regulations. Monitors testing as appropriate.

CPO Radiological Control

Supports testing according to the OTP procedure as directed by the Operations PIC. Notifies the PIC of concerns. exceptions and of $f$-normal conditions during testing. Ensures work performed is within the scope of the applicable Radiological Work Permit (RWP).

\subsection{INFORMATION}

\subsection{TEST GUIDANCE}

Authorization for the implementation of this document is controlied by the associated Engineering Oata Transmittal. Approval indicates that the testing called out in this procedure will verify the required performance of the equipment and provide the required protection for personnel.

Operability testing will be completed to confirm that the modified components are functionally acceptable and will not interfere with movement of the truck and drili rig as they operate in their expected range. Records of the testing will be documented in the left margin and supplied tables within the text of this proceoure.

Initial instrument calibrations shall be conducted prior to Operability testing. Calibrations will not be reconfirmed during ATP/OTP testing.

Discrepancies, deviations, or irregularities involving the test procedure or equipment performance are to be noted, as they occur. on the "Exception/Resolution Data Sheet". An exception number shall be noted in the procedure margin. next to the related test section or step. These exceptions shall be jointly resolved between the Cog Engineer. the Design Authority. the Test Director. and the assigned Quality Assurance Representative. Quality verification of exceptions is only necessary for those exceptions relating to items which initially required Quality verification. All resolutions to the exceptions must be agreed upon by the responsible personnel. documented on the exception list and initialed. Hand written exceptions sheets may be replaced. if replacement sheets are initialed.

No testing shall be done which directly involves faulty equipment. However. at the discretion of the Cog Engineer and with the concurrence of the Test Director. CE and the PIC, tests may proceed on equipment which is not affected by fauity equipment. Any test exceptions caused by equipment failure not associated, directly or indirectly. with the system modification for flamable gas tank sampling. should be dispositioned as "general maintenance" on the Exception/Resolution Data Sheet.

If, due to testing circumstances. on-site modifications of the test procedures are warranted. written changes. ("rediires") riaybe made by the core sampling 
PIC with the written approval (initialing in the left margin) of the Test Director. Cog Engineer and DED. These changes must also be documented on the Exception/Resolution Data sheet prior to test completion sign-off. Amendments shall be per instructions in WHC-CM-6-1. "Standard Engineering Practices". EP4.2. "Testing Requirements. "Rev. 5. Change 3.

Revised operating procedures. written for Push Mode Sample Truck (PMST) operations in flamable gas tanks, are referenced for use within this 0TP. If this pracedure is not released. The procedure will be approved for use in oTp testing by the Test 0irector. Cog Engineer and industrial safety and procedures will be marked as "DRAFT" to prevent unauthorized use in tank farms. The same procedures will be revised for operational use after a formal procedure validation and finalized procedure approval and release. Procedure validations will be performed in parallel with OTP testing, but are not. part of any OTP acceptance criteria and are not required for OTP

completion sign off. Possible procedure change(s) can be relined be the Cognizant Engineer and do not require the use of the Exception/Resolution Data Sheet.

\subsection{REFERENCES}

HNF-SD-WM-ETP-221, Rev. 0 ${ }^{\circ} \quad$ Engineering Task Plan for Modifying Core Sampler Truck \#1 \& 2 for Operation in Flammable Gas Tank

WHC-SO-WM-FOC-048, Rev. 0 Functional Design Criteria for Core Sampling in Flammable Gas Watch List Tanks

WHC-CM-6.1:

EP-4.2. Rev. 5

Standard Engineering Practices:

Testing Requirements

\subsection{SAFETY ISSUES}

To reduce the possibility and severity of injury. all persons in the vicinity of the test equipment must be aware of the following concerns:

WARNING - Exercise caution concerning loose clothing and pinch points while working on or near rotating equipment.

WARNING - Personal protective equipment shall be used during testing as required by Job Hazard Analysis.

WARNING - At times, nitrogen gas will be supplied to the sample truck at high pressure. Breaking containment of a pressurized cavity wi\}? cause a rapid release of gas. All indications must be observed so that each cavity is vented prior to being opened.

WARNING - Avoid all contact with liquid nitrogen. The nitrogen in the liquid nitrogen support trailer nitrogen tank and vaporizer supply line is a liquid and is stored at high pressure and extremely low 
HNF-SO-WM-OTP-229. REV 0 PAGE 5 OF 17

temperatures $\left(-320^{\circ} \mathrm{F}\right)$. Exposure will freeze skin, causing severe "burns".

WARNING - Pressure relief venting of the propane supply on the nitrogen trailer can occur unexpectedly. The vent line for the propane is the copper tubing on the right side of the trafler and the outlet is below and at the rear of the trailer. All flarmability warnings posted on the nitrogen tailer must be observed.

WARNING - If engines need fuel, refuel only when the engines are cool.

WARNING - Stand clear of exhaust pipes on the test equipment.

WARNING - The warning sirens on the sample truck are very loud.

NOTE - Under normal conditions, periodic venting of the nitrogen trajler will occur. Venting is automatic when excessive pressure builds in the nitrogen storage tank. The vent outlet is located near the right rear of the trailer on top of the enclosure.

\subsection{RAOIATION AND CONTAMINATION CONTROL}

All testing will be controlled to prevent contamination release. All test activities must comply with the requirements listed in the RWP issued for this test.

\subsection{QUALITY ASSURANCE}

Quality Assurance shall approve the Operability Test Procedure prior to its release.

\subsection{TYPE Z PRESSURIZATION SYSTEM}

When the purge pressure in the weather cover is too low (less than 0.5 in $\mathrm{H}_{2} \mathrm{O}$ ) an audible alaril sounds and visual alarm will illuminate. To silence the audible alarm. press the "Acknowleoge" button. Also. there is a manual lamp \& alarm test button.

\subsection{ACCEPTANCE CRITERIA}

Items to be tested in this ATP/OTP verify that the Type $Z$ pressurization system meets design requirements specified in WHC-SD-WM-FOC-048. Functional Design Criteria for Core Santipling in Flammable Gas Watch List Tanks. as outlined in Table 1. This ATP/OTP also verifies that basic operation functions of the push mode sampling truck are not inhibited by piping and other components of the Type $z$ Pressurization System and modifications to the shielded receiver lifting frame. 
HNF-SO-WM-OTP-229, REV 0

PAGE 6 OF 17

Table 1: Acceptance Criteria

\begin{tabular}{|c|c|c|c|}
\hline SYSTEM & CRITERIA & \multicolumn{2}{|c|}{$\begin{array}{l}\text { DCM } \\
\text { ITEM ATP/OTP } \\
\text { STEP } \\
\end{array}$} \\
\hline \multirow{8}{*}{ Z-PURGE } & $\begin{array}{l}\text { Protected Enclosure shall be } \\
\text { maintained at a positive pressure of } \\
\text { ot least } 25 \mathrm{~Pa}(0.1 \text { in. water })\end{array}$ & 2.1 & $\begin{array}{l}7.4 .3 .8 \\
\text { and } \\
7.5 .5 .9\end{array}$ \\
\hline & $\begin{array}{l}\text { An alarm wili indicate failure of } \\
\text { protective gas supply to maintain } \\
\text { reguired pressure }\end{array}$ & 2.2 & $\begin{array}{l}7.4 .3 .4 \\
\text { and } \\
7.5 .5 .5 \\
\end{array}$ \\
\hline & $\begin{array}{l}\text { Alarms and displays shall be located } \\
\text { where they can easily be reached. }\end{array}$ & 2.2 .2 & 7.7 .1 \\
\hline & $\begin{array}{l}\text { Indicating lights shall be easily } \\
\text { visible in bright and hazy sunlight. }\end{array}$ & 2.2 .3 & 7.7 .2 \\
\hline & $\begin{array}{l}\text { Verify operating procedure includes } \\
\text { sniffing of weather cover before } \\
\text { initial startup }\end{array}$ & 3 & 7.7 .4 \\
\hline & $\begin{array}{l}\text { Verify label on side of weather cover } \\
\text { says } \\
\text { "Warning - Pressurized Enclosure" }\end{array}$ & 2.4 & 7.7 .3 \\
\hline & $\begin{array}{l}\text { Verify operation procedure provides } \\
\text { for system shutdown after alarm " } 5=E \text { R }\end{array}$ & 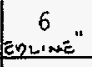 & 7.7 .4 \\
\hline & $\begin{array}{l}\text { Movement of drill rig ie full } \\
\text { traverse. slew and rotation is not } \\
\text { restricted. }\end{array}$ & $N / A$ & Sec. 7.3 \\
\hline $\begin{array}{l}\text { Sample Hoist } \\
\text { Box Vent }\end{array}$ & $\begin{array}{l}\text { Verify HEPA filter installation for } \\
\text { purge gas exhaust }\end{array}$ & 10 & 7.7 .5 \\
\hline $\begin{array}{l}\text { Shielded } \\
\text { Receiver } \\
\text { Lifting Frame } \\
\end{array}$ & $\begin{array}{l}\text { Shielded Receiver movement is not } \\
\text { restricted due to installation of } \\
\text { hydraulic cyl.inders }\end{array}$ & $N / A$ & 7.3.2.13 \\
\hline \multirow{2}{*}{ PMST } & $\begin{array}{l}\text { Verify that modification have not } \\
\text { changed any control functions. }\end{array}$ & $N / A$ & Sec. 7.0 \\
\hline & $\begin{array}{l}\text { Able to interface with required } \\
\text { ancillary equip }\end{array}$ & N/A & $\begin{array}{l}7.1 .2 \\
7.4 \& \\
7.5\end{array}$ \\
\hline
\end{tabular}

1 OCM ITEM refers to Design Compliance Matrix item as listed in HNF-SO-WMETP-221. DCM items are for reference only and are not required for this ATP/OTP 
HNF-SO-WH-OTP-229, REV 0

PAGE 7 OF 17

Each step shall be evaluated and signed off by the cognizant engineer as well os Operations to verify that the equipment is acceptable for field use except for the steps that are marked with an asterisk. These steps are operational steps only and are not required for acceptance.

A1l persons responsible for signing the test completion sign-off sheet shall perform a test review of the completed procedure to verify technical acceptability of all data and resolution of exceptions.

\subsection{RECORDS}

Pertinent operating conditions will be documented when requested in the OTP. Records for the testing of equipment, (Section 7), will be recorded within the procedure. The operator. (and other test personnel requested to do so), will initial in the space provide in the left-hand margin upon satisfactory completion of the designated tasks. All persons initialling within this procedure (including the Exception/Resolution Data Sheet) will initial and sign the Signature Log Sheet.

All test data will be released. as an Operability Test Report. after the conclusion of OTP testing.

\subsection{PREREQUISITES}

\section{I EQUIPMENT AND SUPPLIES}

\begin{tabular}{|c|c|}
\hline EQUIPMENT UNDER TEST & TEST SUPPORT SUPPLIES \\
\hline 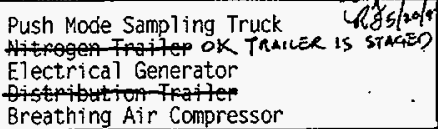 & Support Truck (optiona T) \\
\hline
\end{tabular}

\subsection{PROCEDURES}

NOTE: Some of the referenced procedures may not be used. This ATP/OTP allows either the use of the nitrogen trailer or the breathing air compressor.

T0-020-055 0perate The Aeroflow Mode1 2AN61 Breath Air Compressor

T0-020-056 Operate The Aeroflow Model 2AN137 Breathing Air Compressor

T0-020-451 Setup and Takedown of Core Sample Systems

T0-020-910 Perkins 3.125 Series Generator Set, Operating Procedure

T0-060-345 Liquid Nitrogen Support Trailer and Indeeco Nitrogen Heater Operations 
T0-080-503 Perform Push Mode Core Sampling of Hydrogen/flammable Gas Watchlist Waste Storage Tanks

\subsection{CONDITIONS}

- The Job Mazard Analysis must be complete prior to test start.

- Pre-job safety meetings shall be held at the start of each shift prior to testing.

- Calibration and FM's shall be current and complete prior to testing effected equipment.

- All work packages for installation/functional check of flammable gas modifications must be work-complete prior to related testing.

\subsection{TEST PROCEDURE (EQUIPMENT)}

\subsection{EQUIPMENT IDENTIFICATION AND SETUP}

NOTE: The following steps are intended to verify that fittings and receptacles mate properly for ancillary equipment that is used for this ATP/OTP. If a connection was made previously. VERIFY connection and initial step. Refer to the setup procedure listed in 6.2 if connections or grounding details are required.

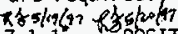

OPfCE DA4. 7.1 .1 POSITION Push Mode Truck equipment listed in the table ntsigin

OP/CE OULW. QND 7.1.2* PIC or COg Engineer. RECORD the identification numbers below. in a convenient location to allow testing.

table below. Use the blank lines to record any changes made (record test sections effected by the change)

\begin{tabular}{|c|c|}
\hline COMPONENT & $\begin{array}{l}\text { IDENTIFICATION }{ }^{2} \\
\text { NUMBER }\end{array}$ \\
\hline Push Mode Core Sample Truck & 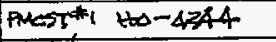 \\
\hline Liquid Nitrogen Trailer & $x y=4+140-64-5170$ \\
\hline Electrical Power Distribution Trailer (EPOT) & $N / A$ \\
\hline Electrical Generator & $50=74-476 / / 40-74-5$ \\
\hline Support Truck & $Z 6$ \\
\hline Breathing Air Compressor (BAC) & Ho-64-4964 \\
\hline
\end{tabular}

for equipment identification, use hoff or other unique identifier 


\section{PAGE 9 OF 17 \\ HNF-SD-WM-OTP-229, REV 0

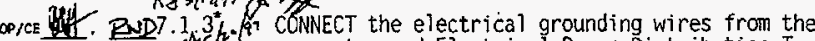

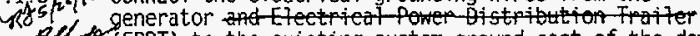

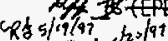 \\ OP/CE \\ RD7.1.4"sys

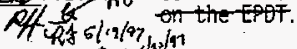

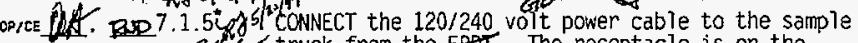

Af 1 truck from the EPOT. The receptacle is on the

N/A RS S/20/97

od/ce CONNECT the 120 volt power cable from the nitrogen

trailer to the generator if nitrogen trailer is used.

\subsection{CORE SAMPLE TRUCK START UP}

NOTE: Whenever truck electronics are powered up without establishing nitrogen supply pressure and type $Z$ pressurization system. The PURGE FAIL alarm wiff sound. This alarm should be acknowledged and no further action taken prior to testing in sections 7.4 and 7.5 .

OPICE 0 . UR 7.2.1 $1^{*}$ OPERATE the generator as required through testing (See operating procedures listed in 6.2 )

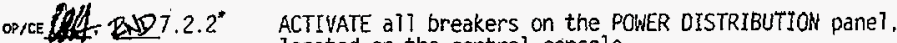
located on the control console.

OP/CE[26f. RND7.2.3 ACKNOWLEDGE the SR Purge Fai] a7arm by pressing the Acknowledge button on the control console.

ACCEPTANCE CRITERIA: Alarm silences

OPJCE 20 START the drill rig engine as per operation procedure iisted in 6.2 (operate the drill engine as required throughout testing.)

\subsection{DRILL RIG MANEUVERING}

NOTE: The sample truck is raised by hydraulic rams, located at the front and rear of the truck, and is leveled busing portable hand levels. The center jack. consisting of two additional rams located on each side of the truck, are used to stabilize the truck for platform rotation. The center jacks are not designed to withstand heavy loads, and should only be lowered after lowering the front and rear lifting jacks. When leveling the truck. lower the rams slowly so that the truck is lifted uniformly. The hydraulic controls associated with leveling are the 4way manual control valves and turn valves which control flow to each of the jacks. 


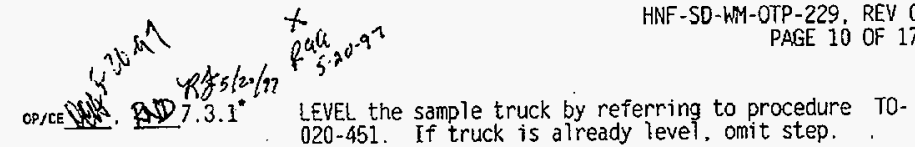

WARNING: For the following platform rotation. drill rig movement, and throughout testing. always ensure that the drill head. Shielded Receiver (SR) and drill rig are positioned to avoid equipment damage prior to moving the rotating platform. Whenever practical. the drill head and SR should be in the up position and the drill rig centered before making any rotation.

\subsubsection{MANEUVERING STEPS}

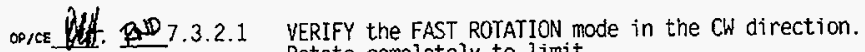 Rotate completely to limit. \\ ACCEPTANCE CRITERIA: Controls function correctly}

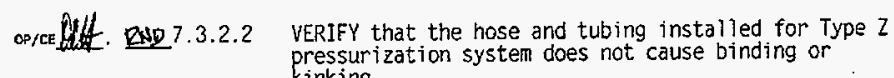
kinking.

ACCEPTANCE CRITERIA: Visual inspection shows no problems OP/CE PU. END.3.2.3 VERIFY the FAST ROTATION mode in the CCW direction.

ACCEPTANCE CRITERIA: Controls function correctly

G/CE OPH. ZND 7.3.2.4 VERIFY that the hose and tubing installed for Type $Z$ pressurization system does not cause binding or kinking.

ACCEPTANCE CRITERIA: Visual inspection shows no problems

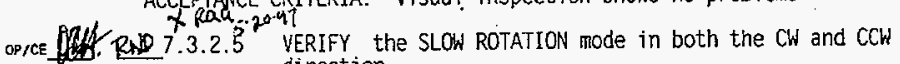
direction.

ACCEPTANCE CPITERIA: Controls function correctly

OP/CE $(1)$. $2.17 .3 .2 .6^{*}$ ROTATE the platform so that the SR is at the rear of the truck.

OP/CE 614 . QWD 7.3.2.7 HOLO the TRAVERSE switch to FORWARD to fully extend the $S R$ end of the drill rig.

ACCEPTANCE CRITERIA: Controls function correctly

op (U) C C 7 7.3.2.8 VERIFY that the hose and tubing installed for Type $Z$ pressurization system does not cause binding or kinking.

ACCEPTANCE CRITERIA: Visual inspection shows no problems

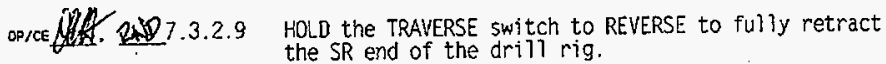




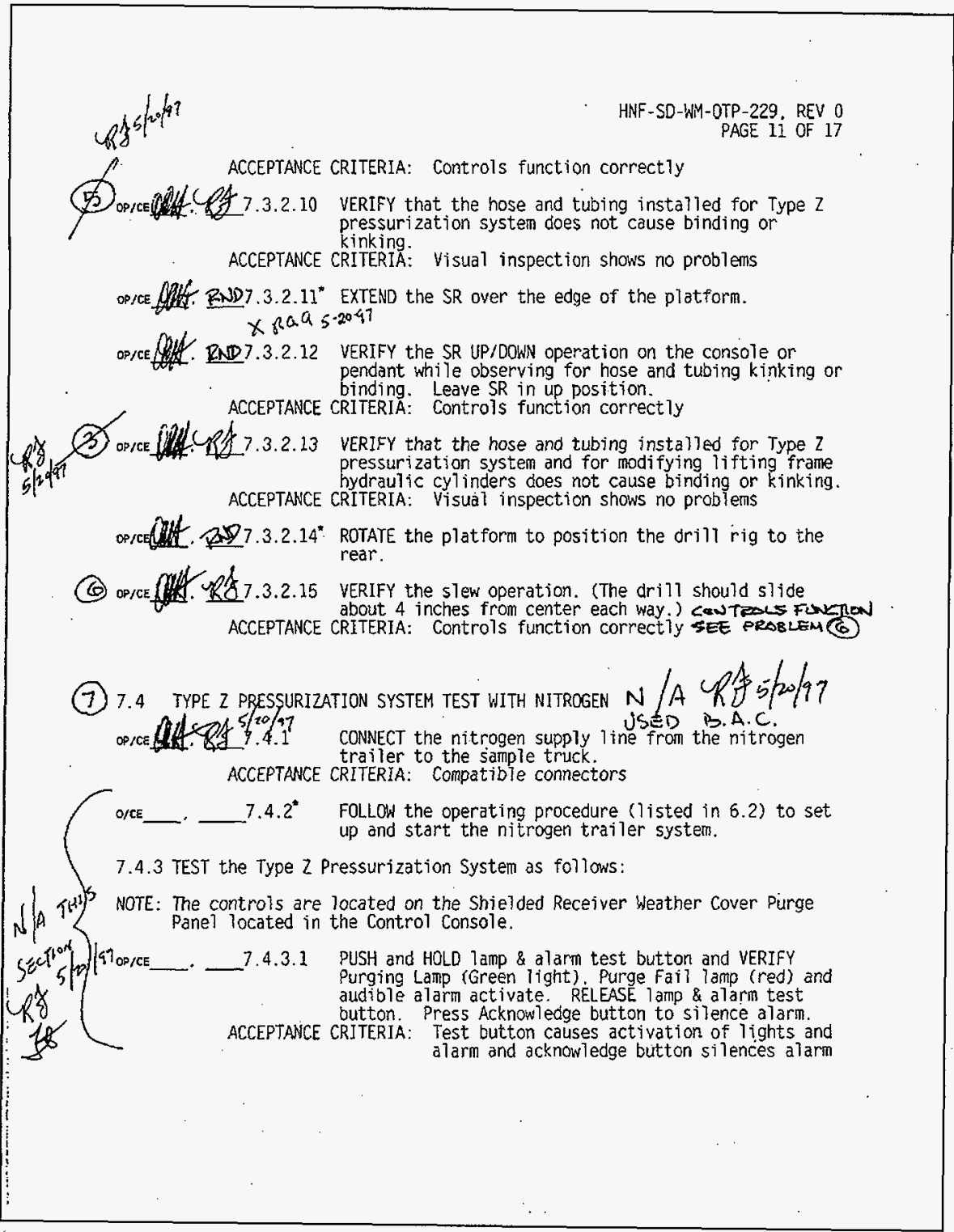




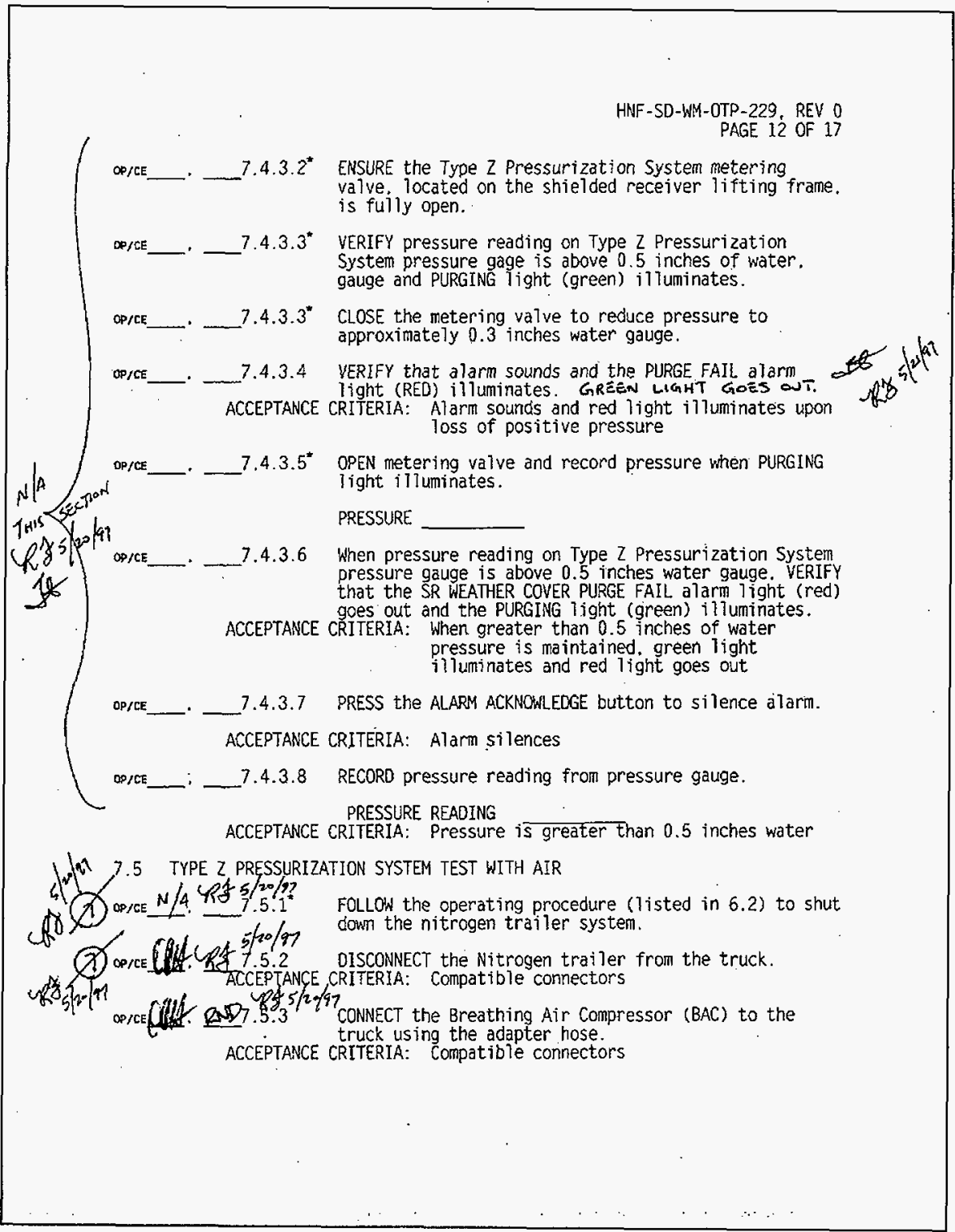




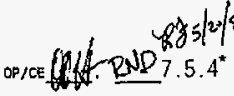

FOLLOW the operating procedure (1isted in 6.2) to set up and start the BAC.

\subsection{5* TEST the Type $Z$ Pressurization System as follows:}

NOTE: The controls are located on the Shielded Receiver Weather Cover Purge Panel located in the Control Console.

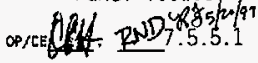

PUSH and HOLD lamp \& alarm test button and VERIFY

Purging Lamp (Green light). Purge Fail lamp (red) and

audible alarm activate. RELEASE 7 amp \& alarm test

button. Press Acknowledge button to silence alarm.

ACCEPTANCE CRITERIA: Test button causes activation of jights and

ak 690 alarm and acknowledge button silences alarm

of

ENSURE the Type $Z$ Pressurization System metering valve located on the shielded receiver lifting frame.

5 hel 49

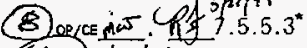
is fuliy open.

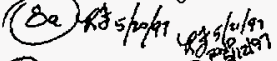

VERIFY oressure reading on Type $Z$ Pressurization

System pressure gage is above 0.5 inches of water.

gauge and PURGING light (green) illuminates. .

(9) op/ck ur. $7.5 .5 .4^{*}$

(1) $5 / 2 / \%$

CLOSE the metering valve to reduce pressure to approximately 0.3 inches water gauge.

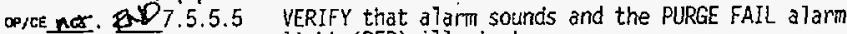
light (RED) illuminates.

ACCEPTANCE CRITERIA: Alarm sounds and red light illuminates upon loss of positive pressure

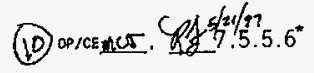

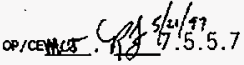

OPEN metering vaive and record pressure when PURGING light illuminatès.

PRESSURE .800

When pressure reading on Type $Z$ Pressurization System pressure gauge is above 0.5 inches water gâuge, VERIFY that the SR WEATHER COVER PURGE FAIL alarm light (red) goes out and the PURGING light (green) il\}uminates.

ACCEPTANCE CRITERIA: - When greater than 0.5 inches of water pressure is maintained, green light

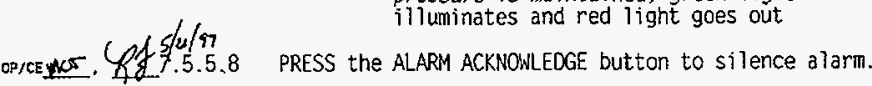

ACCEPTANCE CRITERIA: Alarm silences

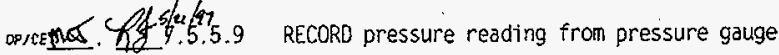

PRESSURE READING .582

ACCEPTANCE CRITERIA: Pressure is greater that 0.5 inches water 
HNF-SD-WM-OTP-229, REV 0

PAGE 14 OF 17

7.6 SHUT DOWN

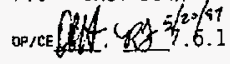

FOLLOW the operating procedures (1isted in 6.2) to shut down the PMST and BAC.

\subsection{OTHER VERIFICATIONS}

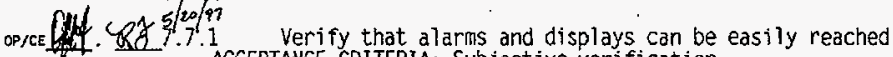
ACCEPTANCE CRITERIA: Subjective verification

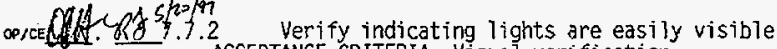

(2.6CEPTANCE CRITERIA: Visual verification

OP/CE 14 . $14.7 \%$ Verify weather cover is labeled "Warning - Pressurized Enclosure"

ACCEPTANCE CRITERIA: VISUal verification

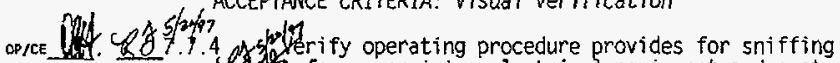

9efore energizing electrical equipment and system ALARM REspoust AFrER a larm activates. PNor swif

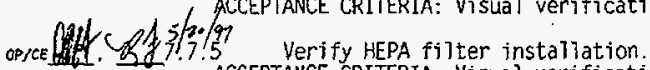

ACCEPTANCE CRITERIA: Visual verification

THE SYSTEM IS NDE REQUIRER TO BE SHUTDOWN WHES AM ALARM IS DETECTEO.

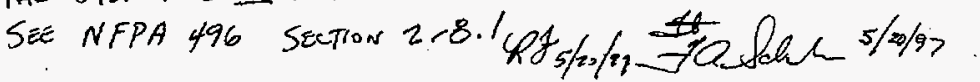


HNF - SD-WM-OTP-229, REV O PAGE 15 OF 17

\subsection{SIGNATURE LOG}

All persons initialing or signing within this procedure (including all data sheets and the test completion sign-off sheet) shall record their signature. initials and printed name in the table below.

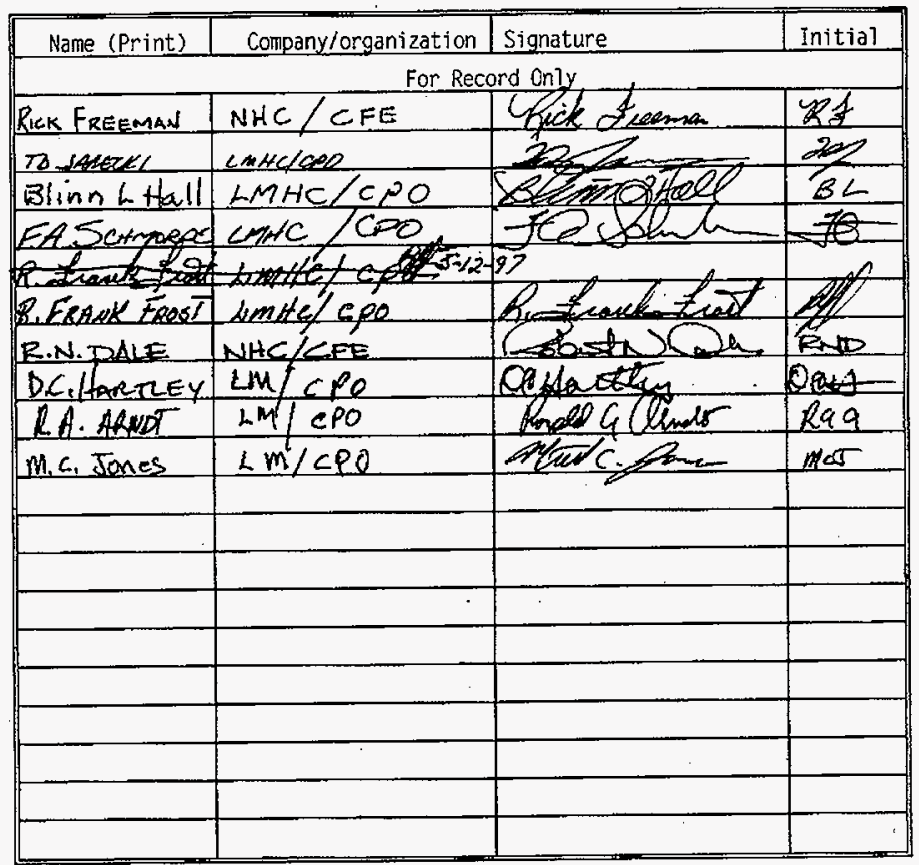


HNF-SD-WM-OTP-229, REV 0

PAGE 16 OF 17

\subsection{TEST COMPLETION SIGN-OFF}

A11 system acceptance and operability tests have been completed as delineated in this ATP/OTP. All exceptions have been documented and resolved as indicated on the Exception/resolution Data Sheet(s). The core sample truck and associated equipment can be operated in a safe manner and are accepted as meeting all test criteria required for push mode operation in flamiable gas tanks and has met the acceptance criteria denated in section 4.7 .

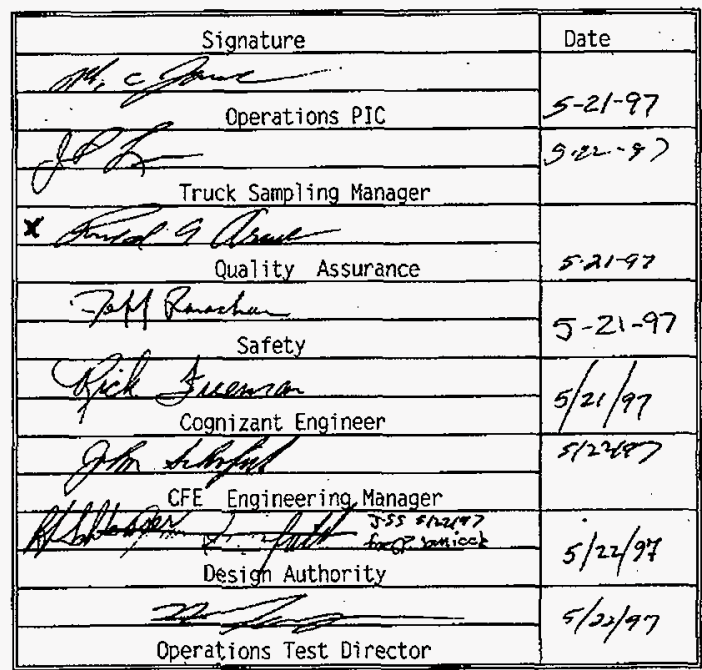

$X$ W.INESS STEPS 7.3.1, 7.3.2.3; 7.3.2.6 AND 7.3.2.12. RGG $5-20-97$

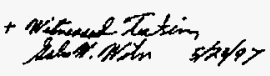


HNF-SD-LM-OTP-229, REV O

PAGE 17 OF 17

\subsection{EXCEPTIONS/RESOLUTION DATA SHEET}

\begin{tabular}{|c|c|c|c|c|c|}
\hline \multicolumn{2}{|c|}{$\begin{array}{l}\text { Except ion } \\
\text { Number }\end{array}$} & \multirow{2}{*}{$\frac{\begin{array}{l}\text { Step } \\
\text { Number }\end{array}}{6.1}$} & \multirow{2}{*}{$\begin{array}{l}\text { DESCRIPTION OF PROBLEM } \\
\begin{array}{l}\text { Distribution traiTer } \\
\text { not used. }\end{array}\end{array}$} & \multirow{2}{*}{$\begin{array}{l}\text { RESOLUTION TO } \\
\text { PROBLEM } \\
\begin{array}{l}\text { Nitrogen trailer not } \\
\text { required. }\end{array}\end{array}$} & $\begin{array}{l}\text { APPROVAL } \\
\text { INITIALS }\end{array}$ \\
\hline 01 & * & & & & R \\
\hline 02 & $\star$ & $\begin{array}{l}7.1 .4, \\
7.1 .5\end{array}$ & $\begin{array}{l}\text { Electrical Power } \\
\text { Distribution Trailer } \\
\text { (EPDT) not used. }\end{array}$ & $\begin{array}{l}\text { Connected truck } \\
\text { directly to } \\
\text { generator. }\end{array}$ & Kot \\
\hline 03 & & $13^{3.2}$ & $\begin{array}{l}\text { A. Pressure switch } \\
\text { eiectrical cord } \\
\text { interference. B. } \\
\text { Purge supply hose to } \\
\text { base plate too long. }\end{array}$ & $\begin{array}{l}\text { A. Adjusted/reroute } \\
\text { electrical cord. B. } \\
\text { Secured hose. }\end{array}$ & 187 \\
\hline 04 & & $\frac{7.3 .2 .}{8}$ & $\begin{array}{l}\text { Purge supply hose too } \\
\text { short during full } \\
\text { outward trayerse of } \\
\text { longyear. }\end{array}$ & $\begin{array}{l}\text { Replaced with a } \\
\text { longer and less } \\
\text { restrictive bungee } \\
\text { cord. }\end{array}$ & MSt \\
\hline 05 & & $\frac{7.3 .2}{10}$ & $\begin{array}{l}\text { Bungee cord hook } \\
\text { pinches purge supply } \\
\text { hose. }\end{array}$ & $\begin{array}{l}\text { Replaced with a } \\
\text { longer and less } \\
\text { restrlctive bungee. } \\
\text { cord. }\end{array}$ & \\
\hline 06 & & $\frac{7.3 .2}{15}$ & $\begin{array}{l}\text { Slew travel in both } \\
\text { directions stretches } \\
\text { and collaspes } \\
\text { hydraulic hoses, makes } \\
\text { contact with safety } \\
\text { rail and electrical } \\
\text { conduit. }\end{array}$ & $\begin{array}{l}\text { Added a caution } \\
\text { block to Ops. proc. } \\
\text { TO-080-503 Rev. F to } \\
\text { HOT slew more than } \\
2^{*} \text { in any direction. }\end{array}$ & 28 \\
\hline 07 & * & 7.4 & $\begin{array}{l}\text { Nitrogen trailer } \\
\text { inoperable. }\end{array}$ & $\begin{array}{l}\text { Skipped this } \\
\text { section. Perform } \\
\text { step } 7.4 .1 \text { \& } 7.5 .2 \text {. } \\
\text { Use breathing air } \\
\text { compressor to } \\
\text { perform test, } \\
\text { section } 7.5\end{array}$ & my \\
\hline 08 & $*$ & $\frac{7.5 .5 .}{3}$ & $\begin{array}{l}\text { Green light did not } \\
\text { illuminate. Plugged } \\
\text { HEPA filters and green } \\
\text { light came on. }\end{array}$ & $\begin{array}{l}\text { Repaired air leaks } \\
\text { per ECN } 631341 \text { l. } \\
\text { Leaks identified } \\
\text { between the sample } \\
\text { hoist box and the } \\
\text { base plate. }\end{array}$ & YXf \\
\hline
\end{tabular}

* Not an acceptance cRiteria. 
HNF-SO-WMM-OTP-229, REV O

PAGE 17 OF 17

\begin{tabular}{|c|c|c|c|c|}
\hline $09 *$ & $\frac{7.5 .5}{4}$ & $\begin{array}{l}\text { Alarm and light } \\
\text { responded at } 0.8 \text { vs. } \\
0.3 \text {. }\end{array}$ & $\begin{array}{l}\text { Repaired air leaks } \\
\text { per ECN } 631341 \text {. } \\
\text { Leaks identified } \\
\text { between the sample } \\
\text { hoist box and the } \\
\text { base plate. }\end{array}$ & Mf \\
\hline $10 *$ & $\begin{array}{l}7.5 .5 . \\
6\end{array}$ & $\begin{array}{l}\text { Purge light does not } \\
\text { illuminate. }\end{array}$ & $\begin{array}{l}\text { Repaired air leaks } \\
\text { per ECN } 631341 . \\
\text { Leaks ident ified } \\
\text { between the sample } \\
\text { hoist box and the } \\
\text { base plate. }\end{array}$ & My \\
\hline $8 a$ * & $7^{7.5 .5 .}$ & $\begin{array}{l}\text { Unabie to verify } \\
\text { pressure with } \\
\text { installed gauge. }\end{array}$ & $\begin{array}{l}\text { Used a calibrated } \\
\text { meter to verify } \\
\text { pressure and } \\
\text { verified pressure } \\
\text { switch settings are } \\
\text { within cal ibration } \\
\text { range }\left(.4^{\prime \prime}-6^{\prime \prime} \mathrm{H} 20\right) \text {. }\end{array}$ & $m$ \\
\hline & & & & \\
\hline & & & & \\
\hline & & & & \\
\hline & & . & & \\
\hline & & & & \\
\hline & & & & \\
\hline & & & & \\
\hline & & & & \\
\hline & & & & \\
\hline & & & & \\
\hline & & & & \\
\hline & & & & \\
\hline & & & & \\
\hline
\end{tabular}

* nOt an acCeptance CRITERia. 


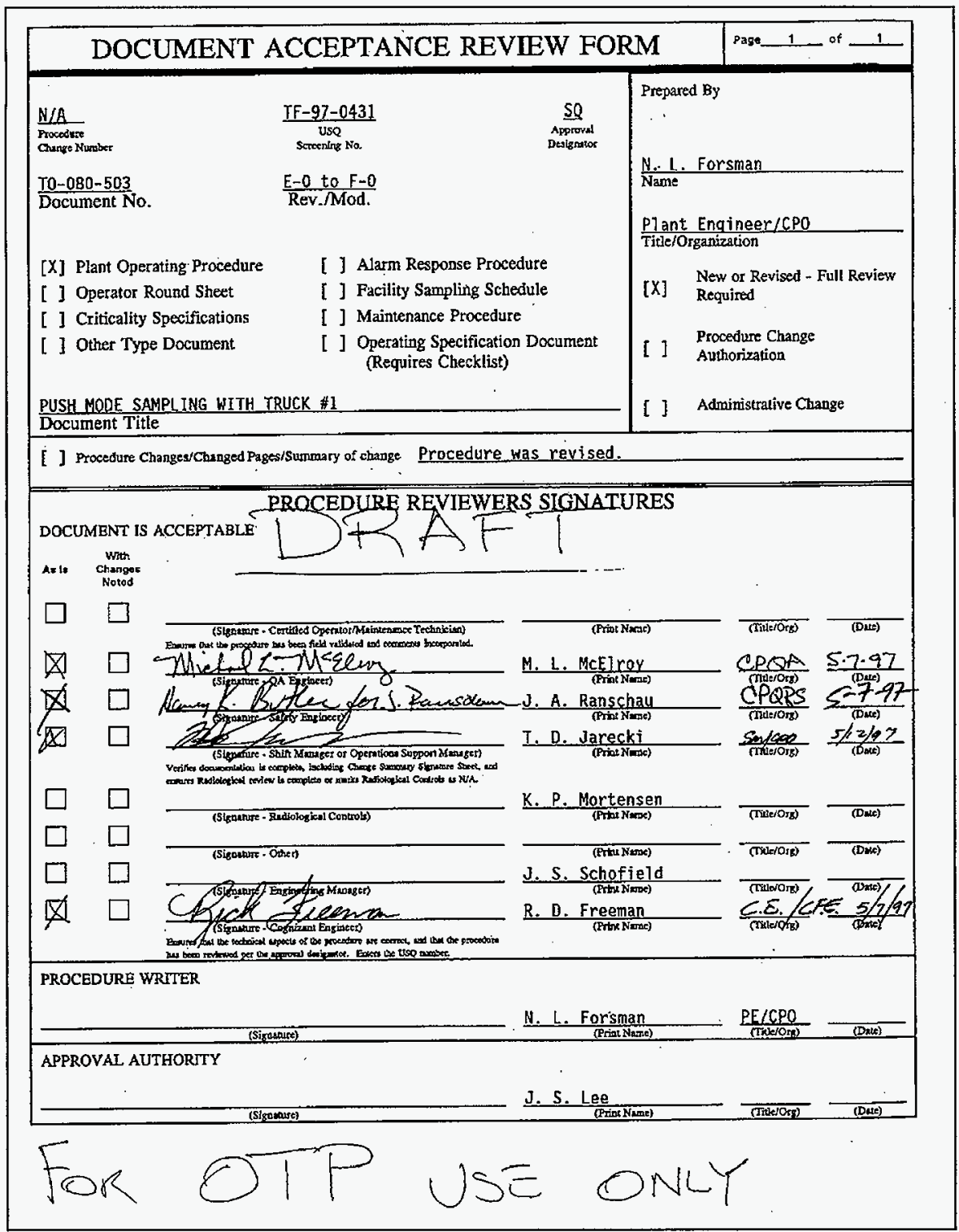

